\title{
JATAHARINI: THE ANCIENT WISDOM OF INFERTILITY AND PERINATAL DEATHS
}

\author{
Deepshikha ${ }^{1 *}$, Garg G.P. ${ }^{2}$ \\ ${ }^{1}$ Assistant Professor, Department of Kaumarbhritya, Uttarakhand Ayurved University Campus, Gurukul Kangri, \\ Haridwar, Uttarakhand, India \\ ${ }^{2}$ Professor and Head of Department, Department of Kaumarbhritya, Uttarakhand Ayurved University Campus, \\ Gurukul Kangri, Haridwar, Uttarakhand, India
}

Received on: 04/01/16 Revised on: 19/01/16 Accepted on: 09/02/16

\author{
*Corresponding author \\ E-mail: deepbhu10@gmail.com
}

DOI: $10.7897 / 2277-4343.07273$

\begin{abstract}
The term 'Jataharini' refers to a group of diseases which are potentially fatal and responsible for perinatal death as well as female infertility. The concept of jataharini is explained in kalpa sthana of Kashyap Samhita. A closer view of the text reveals that this group of diseases includes infectious, genetic, social, environmental and psychological aspects of prenatal and perinatal care. On the basis of etiology, clinical features and time of onset, Jataharini is found to be similar to female infertility, sexually transmitted diseases, neonatal jaundice, twin to twin transfusion syndrome, sudden infant death syndrome, neonatal sepsis, necrotizing enterocollitis, duchenne muscular dystrophy etc.
\end{abstract}

Keywords: Jataharini, Perinatal deaths, Neonatology in Ayurveda, Revati.

\section{INTRODUCTION}

Kashyap has explained the concept of jataharini or revati in the chapter 'revatikalpa' of kalpa sthana in Kashyap Samhita. Revati causes various abnormalities in offspring and infertility in females by afflicting a mother at various stages of reproductive cycle like menstrual phase, pregnancy or puerperium. It adversely affects and destroys the ovum, embryo, fetus or neonate in ante partum, intra partum or post-partum stages. ${ }^{1}$ It is said to invade those women who are non-religious and do not follow norms of physical, mental and social conduct.

\section{Classification of Jataharini}

On the basis of prognosis, jataharini is classified as sadhya (curable), yapya (easily relapsable) and asadhya (incurable). ${ }^{2}$ On the basis of mode of transmission, it is divided into daivi (divine), manushi (human) and tiraschina (animals). ${ }^{3}$

\section{Etiology ${ }^{4}$}

Jataharini bears a wide spectrum of etiology, some of which are listed below:

1. Asocial attitude: Jataharini affects a woman, who is nonreligious, is jealous of respectable persons, egoist, does not have amiable relations in family, inflicts physical injury to others.

2. Dietary causes: Eating meat, unhealthy diet and overeating.

3. Inadequate care of child.

4. Sedentary lifestyle, excess exercise and lack of hygiene.

5. Cross infection from infected women: A pregnant woman can get cross infected by maintaining close relations with an infected woman or by using her articles or garments.

6. Sexual intercourse during pregnancy and intercourse in public water sources.

7. Contamination through soil: A man who walks long distances bare footed can transmit jataharini to his wife.
8. Infected environment, infected animals and excess greed.

Interpretation: When a mother is asocial, egoist and denies to follow the instructions of experienced ones regarding dos and don'ts in pregnancy, she is more likely to suffer from infections, anemia, preterm birth or low birth weight baby and is also possibly neglected by family. As far as dietary causes are concerned, excess fasting results in lesser weight gain of fetus and mother, while unhealthy diet results in anemia or hypertension in mother, resulting in lesser iron stores in fetus and placental insufficiency respectively. Overeating leads to a large for date baby, making parturition complicated with a risk of birth injuries. Inadequate care of baby results in improper nutrition, compromised hygiene and emotional neglect, predisposing baby for protein energy malnutrition, infections, sudden infant death syndrome and delayed motor, social and language milestones. Eating infected or undercooked meat may cause toxoplasmosis which is vertically transmitted to fetus. Toxoplasmosis can also be transmitted through contaminated soil. ${ }^{5}$ Lack of exercise by mother predisposes her to increased weight gain, difficult labour, lesser placental blood supply, pre eclamsia and gestational diabetes mellitus. ${ }^{6}$ Sexual indulgence in pregnancy poses risk of sexually transmitted diseases like HIV infection, syphilis, gonorrhea, chlamydia, viral hepatitis, genital herpes, human papilloma virus etc. ${ }^{7}$ Kashyap has advocated complete avoidance of homes of those infected by jataharini. This reflects upon principle of isolation and prevention of contagious diseases. Animals are also vectors of many diseases. So persons indulged in professions like animal husbandry may contract the same. When a man does excess greed in monetary terms, his child is said to be destroyed by jataharini. A possible explanation may be that such persons will not be attentive to health of children, will not detect their complaints at an early stage and will be reluctant to spend on child's health. Intercourse in public water sources is said to cause jataharini infection. Such activities pose a risk of entry of water borne infections through genitalia. 


\section{Clinical presentation of Jataharini}

Presentations of various types of jataharini are as follows: ${ }^{8}$

Sushka Revati: The lady has no menarche even till 16 years of age and has atrophied breasts and lean shoulders. This represents primary amenorrhea characterized by absence of menses by age 14 years if no secondary sex characters are present and by age of 16 years if secondary sex characters are present. The causes may be low level of FSH and LH, gonadal dysgenesis, turner's syndrome, androgen insensitivity syndrome or mullerian agenesis.

Katambhara: Lady does not have menstruation throughout her life and is emaciated, weak and irritable. This may be case of primary amenorrhea with low body weight. Weight loss can cause elevation in the hormone ghrelin which inhibits the hypothalamic-pituitary-ovarian axis. Elevated concentrations of ghrelin alter the amplitude of GnRH pulses, which causes diminished pituitary release of LH and FSH. ${ }^{9}$

Pushpaghni: The lady has menstrual cycles but remains infertile. She also has thick maxilla and hairy face. This may be attributed to disorders like polycystic ovarian syndrome or disturbances of adrenal hormones and factors causing anovulatory menstruation.

Vikuta: The lady has irregular menses. Irregular menstruation is caused by hypothyroidism, uterine myoma, uterine polyp, infection of uterus, dysfunctional uterine bleeding, cervical cancer, hormonal imbalances, PCOS, etc.

Parisruta: It denotes chronic abnormal vaginal discharges. Chief causes may be bacterial vaginosis, chlamydial infection, pelvic inflammatory disease, trichomoniasis, vaginitis, yeast infections etc.

Andaghni: This includes abortions in second trimester when parts of fetus have been formed. The causes may be uterine malformations, fibroids, cervical anatomical defects, defects of umbilical cord or placenta. ${ }^{10}$

Durdhara: This includes abortions in first trimester when parts of fetus are not formed distinctly. The causative factors may be chromosomal abnormalities or progesterone deficiency. ${ }^{11}$

Kalaratri: This refers to stillbirth or abortion in last trimester. Main causes include bacterial infections, pulmonary hypoplasia, maternal diabetes, hypertension, preeclampsia, abruptio placentae etc. $^{12}$

Stambhini: This refers to decreased fetal movements. Conditions associated with maternal perception of reduced fetal movements are intrauterine death, congenital fetal neurological malformation, fetal hydrops, placental insufficiency, polyhydramnios, fetomaternal hemorrhage, maternal anemia. ${ }^{13}$

Nakini: This term refers to intrauterine death in perinatal period. Causes for the same are preeclampsia, poorly controlled diabetes mellitus, placental abruption, placental insufficiency, fetal malformation and infective diseases.

Pishachi: The neonate dies soon after birth. The term 'pishachi' refers to a fatal cause associated with yellow color. This jataharini is compared to pathological neonatal jaundice as it occurs within 24 hours of birth and is potentially fatal.
Vashya: Vashya jataharini causes fetal death in fifth, sixth or seventh month of pregnancy. The causes may be preterm labor, maternal hypertension, placenta previa, placental abruption, placental insufficiency, cervical incompetence, umbilical cord accidents, maternal diabetes, blood clotting disorders, preeclampsia, epilepsy etc.

Kulkshayakari: In this type of jataharini, death of male offspring occurs, while females survive normally. This may be due to genetic causes involving a recessive allele on $\mathrm{X}$ chromosome like hemophilia, X linked agammaglobulinemia, G6PD deficiency and alport syndrome.

Punyajani: The newborn dies immediately after birth, probably due to severe birth asphyxia.

Paurushadani: Child dies before sixteen years of age. This may be correlated to duchenne muscular dystrophy wherein rapid progression of muscle degeneration, eventually leading to loss of skeletal muscle control, respiratory failure and death occurs.

Sandanshi: Child dies when mother conceives again. This may be similar to parigarbhika or garbhaj phakka wherein early weaning due to mother's pregnancy leads to immunologically weak baby who is prone to fatal infectious diseases. ${ }^{14}$

Indravadva: Death of one or both of twin fetuses. It may be compared to twin to twin transfusion syndrome, twin anemia polycythemia sequence or vanishing twin syndrome.

Badvamukhi: Death of twins with single umbilical cord occurs. This may actually refer to monochorionic and monoamniotic twins or conjoint twins.

Apart from above types of jataharini, Acharya Kashyap has also named Yakshi, Aasuri, Kaali, Varuni, Shasti, Bhiruka, Yamya, Matangi, Bhadrakaali, Vardhika, Chandika, Kapalmalini, Pilipichhika. These are factors which cause neonatal death in first fifteen days after birth. They may include neonatal sepsis, necrotising enterocollitis, tetanus neonatorum, birth asphyxia, preterm births, respiratory distress syndrome etc.

\section{CONCLUSION}

Jataharini is a collection of diseases based on clinical features and disease outcome. Present day knowledge of medical science gives probable explanation for the unknown causes of fetal death and infertility, grouped together as jataharini.

\section{REFERENCES}

1. Kashyap Samhita, edited by Shri Satyapal Bhishagacharya with hindi commentary Vidyotini, Kalpa sthana . Chapter Revati Kalpa/65. Varanasi. Choukhmbha Sanskrit Series. Reprint Edition 2013. p- 194.

2. Kashyap Samhita, edited by Shri Satyapal Bhishagacharya with hindi commentary Vidyotini, Kalpa sthana . Chapter Revati Kalpa/30. Varanasi. Choukhmbha Sanskrit Series. Reprint Edition 2013. p-192

3. Kashyap Samhita, edited by Shri Satyapal Bhishagacharya with hindi commentary Vidyotini, Kalpa sthana. Chapter Revati Kalpa/62. Varanasi. Choukhmbha Sanskrit Series. Reprint Edition 2013. p-194.

4. Kashyap Samhita, edited by Shri Satyapal Bhishagacharya with hindi commentary Vidyotini, Kalpa sthana . Chapter 
Revati Kalpa/8. Varanasi. Choukhmbha Sanskrit Series. Reprint Edition 2013. p-190

5. Caroline Paquet et al. Toxoplasmosis in pregnancy: prevention, Screening and Treatment. SOGC clinical practice guideline. [cited 2015 October 15]. Available from: http://sogc.org/wp-content/uploads/2013/02/gui 285CPG1301E-Toxoplasmosis.pdf

6. Impact of physical activity during pregnancy and postpartum on chronic diseases risk. Special communication. Roundtable concensus statement. [cited 2015 October 15]. Available from:https://www.acsm.org /docs/publications.

7. Mariana Crvalho Costa et al. Sexually transmitted diseases during pregnancy. An Bras Dermatol. 2010[cited 2015 October 15];85(6):767.

8. Kashyap Samhita, edited by Shri Satyapal Bhishagacharya with hindi commentary Vidyotini, Kalpa sthana. Chapter Revati Kalpa/31-46. Varanasi. Choukhmbha Sanskrit Series. Reprint Edition 2013. p-192-194

9. Södersten P, Bergh C, Zandian M. "Psychoneuro endocrinology of anorexia nervosa". Psychoneuro endocrinology (November 2006) [cited 2015 October 15]; 31 (10): 1149-53]

10. Dr.J.S.Dohbit. Abortion: causes and management. [cited 2015 October 15]. Available from:
http://www.gfmer.ch/Medical education/Cameroon 2007/pdf/Abortions_Dohbit_Yaounde_2007.pdf.

11. Bastiaan Jager. Vaginal bleeding in first trimester of pregnancy. [cited 2015 October 15]. Available from:https://www.glowm.com/pdf/Chap-02_Jager.pdf.

12. Dr.J.S.Dohbit. Abortion: causes and management. [cited 2015 October 15]. Available from:http:// www.gfmer.ch/Medical education/Cameroon_2007/ pdf/Abortions_Dohbit_Yaounde_2007.pdf.

13. Julia et al. Reduced fetal movements. The obstetrician and gynecologist. Volume 11, Issue 4. [cited 2015 October 15]. Available from: http://onlinelibrary.wiley.com /doi/10.1576/toag.11.4.245.27527/pdf.

14. Tikole Rushikesh V., Kulkarni R., Shailaja U., Nithin S.A., Mallanvar V., Nayankumar S.,Tikole Yogesh V. Nutritional deficiency disorders in paediatrics: An Ayurvedic perspective. Int. J. Res. Ayurveda Pharm. 2013;4(4):605$607 \mathrm{http}: / / \mathrm{dx}$. doi.org/10.7897/2277-4343.04431

\section{Cite this article as:}

Deepshikha, Garg G.P. Jataharini: The ancient wisdom of infertility and perinatal deaths. Int. J. Res. Ayurveda Pharm. Mar - Apr 2016;7(Suppl 2):138-140 http://dx.doi.org/10.7897/ 2277-4343.07273

Disclaimer: IJRAP is solely owned by Moksha Publishing House - A non-profit publishing house, dedicated to publish quality research, while every effort has been taken to verify the accuracy of the content published in our Journal. IJRAP cannot accept any responsibility or liability for the site content and articles published. The views expressed in articles by our contributing authors are not necessarily those of IJRAP editor or editorial board members. 